liquid chromatography. IX.) Yoshinori TAKata* and Giichi Muto** (*Hitachi Research Laboratory, Hitachi, Ltd., 4026, Oomika, Kuji-machi, Hitachishi, Ibaraki; **Institute of Industrial Science, University of Tokyo, 7-22-1, Roppongi, Minato-ku, Tokyo)

A method for the coulometric detection of silicate, phosphate, and germanate ions with the molybdoheteropoly acids after the separation with anionexchange chromatography was investigated. The size of the separation column used was $9 \mathrm{~mm}$ in inside diameter and $80 \mathrm{~mm}$ in length, and strong base anion exchange resin was packed in the column. Good results was obtained when $0.4 \mathrm{M} \mathrm{NaOH}$ was used as the eluent for the separation of silicate and germanate ions, and $0.4 \mathrm{M} \mathrm{NaOH}-0.02 \mathrm{M} \mathrm{Na}_{2} \mathrm{SO}_{4}$ for silicate and phosphate ions. The optimum conditions for the coulometric detection of these ions are the following : the working electrode potential kept at $0.10 \mathrm{~V}$ vs. ferri-ferrocyanide, $\mathrm{H}_{2} \mathrm{SO}_{4}$ concentration in $(0.4 \pm 0.1) \mathrm{N}$, and reaction time for $5 \mathrm{~min}$ at $40^{\circ} \mathrm{C}$. The detection limit was $0.2 \mathrm{ppm}(0.1 \mu \mathrm{g}$, as $\mathrm{Si}$ and P) for silicate and phosphate ions. The linear dy- namic range was $(0.2 \sim 250) \mathrm{ppm}$ (as $\mathrm{P}$ ) for phosphate and $(0.2 \sim 50) \mathrm{ppm}$ (as Si) for silicate. And the coefficient of variation at $50 \mathrm{ppm}\{c a .200 \mathrm{ppm}$ (as Ge) for germanate $\}$ was less than $2 \%$ for these three ions. Alkaline earth and heavy metal ions more than $1000 \mathrm{ppm}$ interfered the determination because of their co-precipitation. Ions of $\mathrm{As}(\mathrm{V}), \mathrm{Sb}(\mathrm{V})$ and $\mathrm{Cr}(\mathrm{VI})$, however, did not interfere the detection. The method is useful for the determination of $\mathrm{ppm}$ level of these ions in water.

(Received May 4, 1978)

\section{Keywords}

Coulometry

Germanate ion

Ion-exchange chromatography

Molybdoheteropoly acid

Phosphate ion

Silicate ion

\title{
フェノール溶解法による高純度金属マグネシウム中の 酸化マグネシウムの定量
}

\author{
松 本 健 ${ }^{\circledR}$, 小泉 貞之，木羽 敏泰* \\ (1978 年 6 月 14 日受理)
}

\begin{abstract}
$100 \mathrm{ml}$ 二ロフラスコにフェノール $40 \mathrm{ml}$ を入れ, 予備加熱して脱水してからフラスコ内を窒素ふん い気とした後, 試料の高純度マグネシウム片を加え, 加熱還流すると, 金属はマグネシウムフェノオキ シドとなって溶解し, 酸化物は溶けないで残さとなる. 無水メタノールを加えて希釈後, 酸化物残さを 沪別し希塩酸で溶解した水溶液について，マグネシウムの量を原子吸光法で定量し酸化物量を求める. 本法の精度は高く，金属表面及び内部の酸化物の総量を簡単迅速に定量できる。
\end{abstract}

\section{1 緒 $\overrightarrow{\overrightarrow{1}}$}

金属マグネシウムは空気中で酸化されやすいため，漓 純度の品位の金属であっても精鍊工程や保存中に拈い て，生成した酸化マグネシウムを金属の内部や表面に含 有している．この微量の酸化マグネシウムは金属マグネ シウムの諸性質に影響を与えるので，高純度金属マグネ シウム中の酸化マグネシウムを簡単迅速に, かつ正確に **金沢大学理学部化学教室: 石川県金沢市丸の内 1-1
定量することは望まれるところである。マグネシウムと 酸化マグネシウムはともに各種試薬に対する化学的性質 が類似していること，及び含まれる酸化マグネシウムが 微量であることから，他金属に適用される酸溶解水素発 生法や臭素-メタノール法は適用乙難く, 又真空昇華法1) も不適である．既に両者のク口ム酸に対する溶解性の差 を利用した方法2) 4)が報告されているが，金属マグネシ ウムが水に溶解することを考慮すると，水溶液系を用い るのは好ましくない，又，著者らが先に高純度カドミウ 
ム中の微量の酸化カドミウムを定量するのに，用いた金 属をアマルガム化する方法5)をマグネシウム金属につい て行ったが，マグネシウムーアマルガムの強い活性のた め用いることができなかった. 別に小田ら6) は八ロゲン アルキルに対する反応性の美を用いて酸化マグネシウム を定量しているが操作が複雑で熟練を要する.

著者らは多くの非水溶媒系についてマグネシウム及び 酸化マグネシウムとの反応を試験し，ついにフェノール を選んだ。すなわち酸化マグネシウムは全くフェノール に溶解しないが，金属マグネシウムは極めてよくフェノ ールに溶解することを見いだした．よって高純度金属マ グネシウム試料をフェノールで処理し，残った酸化マグ ネシウムを沪別して，これを塩酸に溶解し原子吸光法を 用いて高い精度と再現性をもって定量できたのでここに 報告する.

\section{2 陚薬と装置}

\section{1 試 薬}

金属マグネシウム: 三津和化学薬品製切削片状金属、 グネシウム $(99.99 \%$ 表示)，和光純薬製リボン状金属 マグネシウム $(99.5 \%$ 表示)，か粒状金属マグネシウム ( 1 級)，英国製リボン状金属 マグネシウム $(99.9 \%$ 表 示）を用いた。発光分光分析により调べた結果, 三津和 化学薬品製, 和光純薬製のものは他元素の分析線でその 存在を認めらるものはなかった。

マグネシウム標準溶液 : 三津和化学薬品製金属マグネ シウム $(99.99 \%)$ の表面を希塩酸, アセトン，エチル エーテルの順に洗浄し, 風乾したものの $1 \mathrm{~g}$ を精ひょう し, 塩酸 $(1+1) 20 \mathrm{ml}$ に溶解, 水で 11 の定容とし, $\mathrm{Mg}^{2}+1 \mathrm{mg} / \mathrm{ml}$ の溶液を得た。乙の溶液をストック溶 液とし，使用の都度適当に希釈して用いた。

酸化マグネシウム: 市販の試薬酸化マグネシウムには しばしば微量の他金属の酸化物を含むことを発光分光分 析, X線回折による試験で知りえたので，乙れらを用い ないで本研究では次のように調製した。上述の純金属マ グネシウムを $6 \mathrm{M}$ 塩酸の少量に溶解し, 水を加えて希 釈し, 希アンモニア水を加光て $\mathrm{pH} 7$ とし水酸化マグ ネシウムの沈殿を形成させる、沈殿のあるまま溶液を蒸 発乾固し, 電気炉で $(500 \sim 600)^{\circ} \mathrm{C}$ で恒量になるまで熱 する. 得られた酸化マグネシウムにつき $\mathrm{X}$ 線回折四を求 めたが, ASTM カード記載のものと一致し, 又発光分 光分析によっても他元素の分析線は認められなかった。

フェノール: 市販特級フェノールを使用の都度, 適量 を反応フラスコに入れ, 沸点の $180^{\circ} \mathrm{C}$ まで加熱し, 更 に $5 \mathrm{~min}$ 加熱を続けることにより，含まれる微量の水 をフェノールとの共沸混合物 (bp $\left.99.5^{\circ} \mathrm{C}\right)$ として本研 究に影響を与えない程度に除いて用いた。

メタノール:市販 1 級メタノールにヨウ素と金属マグ ネシウムを加え，加熱還流し含まれる水をすべて反応さ せた後, 使用の直前に分留精製し, 本研究に影響を与元 ない程度に脱水して用いた。
窒素ガス: 市販の窒素ボンベ（純度 $99.9 \%$ 以上）か ら得られるものを，ピロガロール20 g, 水酸化カリウ ム $20 \mathrm{~g}$ を $60 \mathrm{ml}$ の水に溶解した溶液に通し，更に亜鉛 アマルガムを加えたバナジウム(II) 溶液に通して酸装 を除いた後, 乾燥用塩化カルシウム管に通して水分を除 いて用いた。

炭酸ガス: キップの装置を用いて大理石と塩酸を作用 させて発生させたものを用いた。

\section{2 装}

原子吸光装置：日立製 170-50 型, 浜松テレビ社製中 空陰極ランプ（マグネシウム用 $: 2854 \AA$ ), 空気ーアセチ レン炎を用いた。

X線回折装置: 理学電機製 GEIGER FLEX

発光分光装置: 島津製 GL-170 型, スリット幅 0.010 $\mathrm{mm}$, 露光時間は標準鉄 $15 \mathrm{~s}$, 試料 $30 \mathrm{~s}$ で断続フーク 発光させ,フジプロセス乾板に撮影した後, 島津投影式 測微光度計 PD-20 型を用いてスペクトル線を検出した。

Karl Fisher 蒤定装置：メトローム社製 E452

グローブボックス $: 60 \mathrm{~cm} \times 60 \mathrm{~cm} \times 35 \mathrm{~cm}$ のステンレ ス板で組み立てた。外壁に穴をあけ，䇪素ガスを通ずる 管と吸引沪過用の管を取り付けた。

\section{3 実験, 絬果及び討論}

\section{1 金属マグネシゥムのフェノールへの溶解}

金属マグネシウムはフェノールと反応し，マグネシウ ムフェノオキシドを生成して溶解する. この反応が化学 量論的に進むことを以下に示すように発生する水素を測 容して確かめた.

$$
\mathrm{Mg}+2 \mathrm{PhOH} \longrightarrow \mathrm{Mg}(\mathrm{OPh})_{2}+\mathrm{H}_{2} \uparrow
$$

測定装置はFig. 1 のように組み立てた. $100 \mathrm{ml}$ の ニロフラスコ(F)にフェノール $40 \mathrm{ml}$ と金属マグネシ

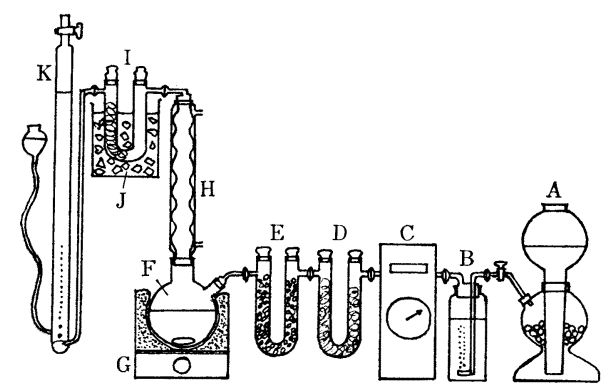

Fig. 1 Apparatus for measuring hydrogen generated by the reaction between magnesium metal and phenol

A : Kipp's gas generator $\left(\mathrm{CO}_{2}\right.$ gas $) ; \quad \mathrm{B}$ : Washing bottle; C: Gas meter; D : Absorbent cotton; E : Calcium chloride anhydrous tube; $\mathrm{F}:$ Reaction flask; G : Heater and mixer; $\mathrm{H}:$ Air condenser; I : Trap (glass wool); J : Ice-water bath; $\mathrm{K}:$ Gas burette $(50 \mathrm{ml})$, filled with $50 \%(w / v) \mathrm{KOH}$ solution 
ウム $(33 \sim 35) \mathrm{mg}$ を入れ,小型のテフロン製かくはん子 を入れて，一方の口に空気冷却器 $(\mathrm{H})$ を取り付ける. 冷 却器の先端を $50 \%$ 水酸化カリウム水溶液を満たしたガ スビュレット $(\mathrm{K})$ に連結する. 空気冷却器とガスビニレ ットの間にはフェノールガスを捕集するためのトラップ （I）を入れる. 反応フラスコのもう一方のロからガス メーター $(\mathrm{C})$ を通して炭酸ガスを流し，装置全体の空間 を炭酸ガスで十分に置き替えた後, 反応フラスコをマン トルヒーター $(\mathrm{G})$ で加熱し，フェノールを磁気かくはん しながら反応を開始する，加熱を $200^{\circ} \mathrm{C}$ に保ち，発生 する水素を炭酸ガスの流れによりガスビュレット $(\mathrm{K})$ に 集める. 反応終了後，ガスビュレット中に捕集された水 素ガス量を測容し, 更に爆発法により水素量を求めた.

Table 1 は金属マグネシウムがフェノールに式 (1) に 従って溶解することを示す.

Table 1 Gas analysis of hydrogen generated by the reaction between magnesium metal and phenol

\begin{tabular}{ccc}
\hline \multirow{2}{*}{\begin{tabular}{c} 
metal taken \\
\cline { 2 - 2 } calculated
\end{tabular}} & $\mathrm{H}_{2}(\mathrm{ml})$ \\
\hline $33.5_{3}$ & 33.4 & 33.2 \\
$35.2_{1}$ & 35.0 & 35.3 \\
$35.0_{0}$ & 34.7 & 35.0 \\
\hline
\end{tabular}

$\dagger 26.8^{\circ} \mathrm{C}, 756.2 \mathrm{mmHg}$

\section{2 酸化マグネシウムとフェノールとの反応}

空気冷却器を取り付けた $100 \mathrm{ml}$ 二ロフラスコにフェ ノール $40 \mathrm{ml}$ を入れ，これに酸化マグネシウム $(2 \sim 75)$ $\mathrm{mg}$ を投入し，小型のテフロン製かくはん子によりフェ ノールを磁気かくはんしながらマントルヒーターで加熱 還流する. $(30 \sim 60)$ 分後に加熱を止め, $(50 \sim 60){ }^{\circ} \mathrm{C} に$ 放 冷し, 無水メタノール $30 \mathrm{ml}$ を加光て希釈した後, 反応 溶液をガラスフィルター (1G5)を通して吸引沪過する. フィルター上に捕集された酸化マグネシウムを無水メタ ノールで十分に洗浄した後, $2 \mathrm{M}$ 塩酸 $50 \mathrm{ml}$ を加えて溶 解し，定容フラスコに移し入れ，定容とした溶液中のマ グネシウムを原子吸光法で定量した. Table 2 に示すよ

Table 2 Dissolution of $\mathrm{MgO}$ by reaction with phenol

\begin{tabular}{ccc}
\hline $\begin{array}{c}\mathrm{MgO} \text { taken } \\
(\mathrm{mg})\end{array}$ & Heating time at $180^{\circ} \mathrm{C}$ & $\begin{array}{c}\text { Recovery of } \mathrm{MgO} \\
(\%)\end{array}$ \\
\hline 2.42 & 30 & 98.7 \\
12.0 & 30 & 99.4 \\
41.4 & 30 & 99.5 \\
74.1 & 30 & 99.0 \\
30.2 & 60 & 99.6 \\
\hline
\end{tabular}

らに酸化マグネシウムはフェノールに全く溶解しない。

\section{3 フェノール及びメタノール中の水分の影響}

反応溶媒であるフェノール及び希䆏剤であるメタノー ルに含まれる微量の水分は, 反応生成物であるマグネシ ウムフェノオキシドを加水分解し, 又フェノールに不溶 の水酸化マグネシウムを生成し，䛊差を与えると考えら れる。

市販特級フェノールに含まれる水分はカールフィシャ 一法で測定したところ，0.05\% であることが分かった． しかし使用に際してあらかじめフェノールを加熱し，含 まれる水をフェノールとの共沸韲合物として除去する と，その含水率は $0.005 \%$ となった，そこで,この脱水 フェノールに既知量の水を添加し，水の影響について調 ベた. 空気冷却器を取り付けた $100 \mathrm{ml}$ の二ロフラスコ に脱水フェノール $40 \mathrm{ml}$ を入れ, これにマイクロシリン ジを用いて一定量の水を添加した後，マントルヒーター で加熱し磁気かくはんする.フェノールが泓騰したとこ ろで反応フラスコの共せんをした一方の山から，精ひょ らした金属マグネシウムを投入する。直ちに水素ガ入を 発生しながら金属マグネシウムは溶解する．水素ガスの 発生がもはや認められなくなってから，更に 10 分間加 熱を続け，金属マグネシウムを完全に溶解する，反応》 ラスコを $(50 \sim 60)^{\circ} \mathrm{C}$ まで放冷した後, 無水ょタノール $30 \mathrm{ml}$ を添加して反応溶液を希釈する．反溶液をガラ スフィルター（１Ｇ５）を通して吸引沪過する。無水メタ ノール $200 \mathrm{ml}$ を用いて反応フラスコ, ガラスフィルタ 一を十分に洗浄した後，フィルター上に捕集されたマグ ネシウムを $2 \mathrm{M}$ 塭酸を加えて溶解し, 定容フラスョに移 し入れ，水で定容とした後，溶液中のマグネシウムを原 子吸光法で定量した．Fig. 2 はその結果を示す．酸化マ グネシウムの值は溶媒の含水率が高いと高くなり, 明ら かに加水分解によると考えられる. しかし，0.2\% 以下 の含水率では一定値が得られることから，著者のように 作製した脱水フェノールは使用して差し支えないことが 分かる. 同㥞に無水メ夕ノール（含水率 $0.02 \%$ ) に一定 量の水を添加したものを用いて，フェノールについて行 ったのと同じ操作を行った. Fig. 3 はその結果を示し， $1 \%$ 以下の含水メタノールではその影響は見られなかっ た．以上の操作はすべて乾燥窒素ガ入ふんい父下でグ口 ーブボックス中で行った.

\section{4 金属マグネシウム中の酸化マグネシウムの定量}

$3 \cdot 1 \sim 3.3$ の実験の結果, フェノール溶解法により金属 マグネシウムと酸化マグネシウムが分離できることが分 


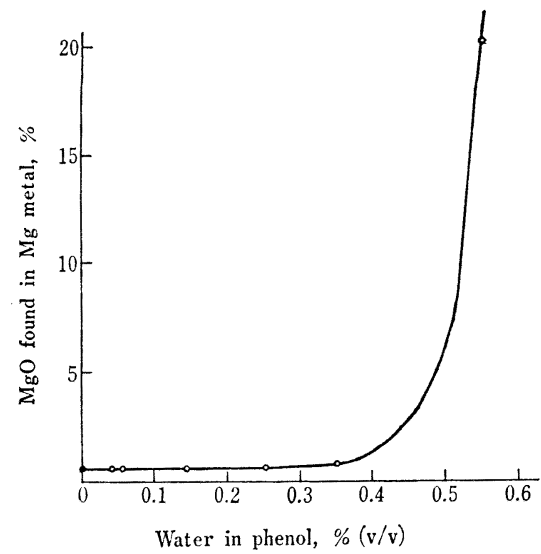

Fig. 2 The effect of water in phenol on the dissolution of magnesium metal with phenol

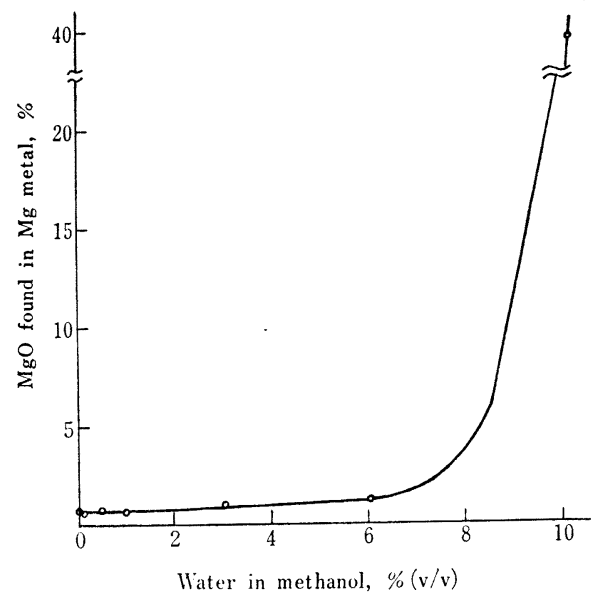

Fig. 3 The effect of water in methanol on the dissolution of magnesium metal with phenol

かったので，高純度金属マグネシウム中の微量酸化マグ ネシウムの定量操作法を次のように組み立てた。 三津和 化学薬品製切削片状金属マグネシゥム $(99.99 \%)$, 和光 純薬製りボン状金属マグネシウム $(99.5 \%)$, か粒状金属 マグネシウム ( 1 級)，英国製金属マグネシウム $(99.9 \%)$ を使用して，それらに含まれる酸化マグネシウムの定量 を行った．すべてのガラ人器具は加熱乾燥後, デシヶー ター中で保存したものを使用し，乾燥窒素が入のふんい 気下でグローブボックス中で全操作を実施した.

$100 \mathrm{ml}$ 二ロフラスコにフェノールの $40 \mathrm{ml}$ を入れ， 一方の口に小型の蒸留用コンデンサーを取り付け，他方
の口には共せんをする.フラスコをマントルヒーターで 加熱し，フェノールが溶液となった時点で共せんをした ロから，小型のテフロン製かくはん子を投入し，フェノ 一ルを磁気かくはんする，加熱を続けフェノールが沸騰 してから，5 分間フェノールを蒸留する．この操作で含 まれる微量の水はフェノールとの共沸混合物として，反 忘フラスコから除去できる. 次に蒸留用コンデンサーを すばやく取り去り，代わりに小型の球入れ冷却器を反応 フラスコに取り付ける. 冷却器は水を通さず空気冷却と する.フェノールを加熱, 磁気かくはんしながら, 共せ んをした口から精ひょうしたマグネシゥム金属試料を投 入する. 直ちに水素ガスを発生しながら金属マグネシウ ムが溶解する. 水素ガスの発生が認められなくなってか ら，更に 10 分間加熱を続け，金属マグネシウムを完全 に溶解する. 反応フラスコを $(50 \sim 60){ }^{\circ} \mathrm{C}$ に放冷後, 反 応溶液に無水メタノール $30 \mathrm{ml}$ を添加し, マグネシウム フェノオキシドを溶解，希釈した後，フェノールーメタ ノール溶液をガラスフィルター (1G5) を通して吸引 沪過する。不溶残さの酸化マグネシウムはフィルター上 に捕集される. 無水メタノールで十分洗浄した後, ガラ スフィルター上に $2 \mathrm{M}$ 塩酸の $50 \mathrm{ml}$ を注ぎ入れ, 酸化 マグネシウムを溶解する. 純水で更に十分に洗浄して, その溶液をメスフラスコに移し入れ，定容とした溶液中 のマグネシウムを原子吸光法により定量した. Table 3, 4，5，6 とその結果を示す. Table 3，4 から分かるよ

Table 3 Determination of total $\mathrm{MgO}$ in $\mathrm{Mg}$ metal (flinders)

\begin{tabular}{clll}
\hline $\begin{array}{c}\text { Mg metal taken } \\
(\mathrm{mg})\end{array}$ & \multicolumn{2}{c}{$\mathrm{MgO}$ found } & \\
\hline 18.8 & 0.041 & 0.22 & \\
55.3 & 0.088 & 0.16 & $\vec{x}=0.20 \%$ \\
102 & 0.245 & 0.24 & $n=6$ \\
102 & 0.177 & 0.17 & $\sigma=0.0325$ \\
102 & 0.166 & 0.16 & c. v. $=16.3 \%$ \\
103 & 0.232 & 0.22 & \\
\hline
\end{tabular}

Purity of $\mathrm{Mg}$ flinders : $99.99 \%$

Table 4 Determination of total $\mathrm{MgO}$ in $\mathrm{Mg}$ metal (ribbon)

\begin{tabular}{cccl}
\hline $\begin{array}{c}\text { Mg metal taken } \\
(\mathrm{mg})\end{array}$ & \multicolumn{2}{c}{$\mathrm{MgO}$ found } & \\
\hline 35.1 & 0.20 & 0.57 & \\
33.7 & 0.20 & 0.59 & $\bar{x}=0.61 \%$ \\
34.1 & 0.21 & 0.62 & $n=7$ \\
31.6 & 0.20 & 0.63 & $\sigma=0.0245$ \\
34.4 & 0.22 & 0.64 & $\mathrm{c.v}=4.02 \%$ \\
36.5 & 0.23 & 0.63 & \\
33.7 & 0.20 & 0.59 & \\
\hline
\end{tabular}

Purity of $\mathrm{Mg}$ ribbon : $99.5 \%$ 
Table 5 Determination of total $\mathrm{MgO}$ in $\mathrm{Mg}$ metal (ribbon)

\begin{tabular}{clll}
\hline $\begin{array}{c}\mathrm{Mg} \text { metal taken } \\
(\mathrm{mg})\end{array}$ & \multicolumn{2}{c}{$\mathrm{MgO}$ found } & \\
\hline 21.0 & $(\mathrm{mg})$ & $(\%)$ & \\
22.1 & 0.75 & 3.57 & $\bar{x}=3.43 \%$ \\
25.4 & 0.73 & 3.30 & $n=5$ \\
30.0 & 0.91 & 3.58 & $\sigma=0.151$ \\
100 & 0.96 & 3.20 & c. v. $4.40 \%$ \\
\hline
\end{tabular}

Purity of $\mathrm{Mg}$ ribbon : $99.9 \%$

Table 6 Determination of total $\mathrm{MgO}$ in $\mathrm{Mg}$ metal (granule)

\begin{tabular}{cccc}
\hline $\begin{array}{c}\text { Mg metal taken } \\
(\mathrm{mg})\end{array}$ & \multicolumn{2}{c}{$\mathrm{MgO}$ found } & \\
\hline 26.6 & 0.95 & 3.57 & \\
29.3 & 0.88 & 3.00 & $\bar{x}=3.30 \%$ \\
65.3 & 2.11 & 3.23 & $n=6$ \\
66.6 & 2.24 & 3.36 & $\sigma=0.228$ \\
79.0 & 2.42 & 3.06 & c. v. $-6.91 \%$ \\
120 & 4.31 & 3.59 & \\
\hline
\end{tabular}

Purity of $\mathrm{Mg}$ granulc : Extra pure

らに, 99.99\%の高純度の金属マグネシウムであっても， $0.20 \%$ の酸化マグネシウムを含み， $99.5 \%$ の純度のも のは $0.61 \%$ の酸化マグネシウムが介在している．高純 度金属マグネシウムの保管の難しさを表している。しか し， $\sigma$ 值は $0.0325 ， 0.0245$ と精度よく，よい再現性で 定量できた. Table 5 は研究室で十数年放置されていた もので，顕著に金属表面が酸化されていたため，その結 果は $99.9 \%$ の高純度表示であっても，酸化マグネシウ 么 $3.43 \%$ と極めて高い含有率を得た. 又, Table 6 の か粒状試料はとの表面積が大きいことと, 純度が比較的 低いことから，酸化マグネシウムの含有率は $3.30 \%$ で あった．変動係数は $4.40 \% ， 6.91 \%$ といずれも精度， 再現性ともに十分であった.

\section{5 本法の適合性}

3.4 で本法は十分な精度と再現性で金属マグネシウム 中心酸化マグネシウムを定量しらることが分かった。 そ こで，金属マグネシウムの表面に形成される酸化マグネ シウムについて考察し，本法の適合性を確かめた。

純度 $99.5 \%$ のリボン状金属マグネシウムを希塩酸で 洗浄し，表面の酸化マグネシウムを除去した後，水，工 タノール，アセトンで順次洗浄して，シリカゲルの入っ たデシケーター内に置き，(15〜20) 分間乾燥した. この 金属マグネシウムを $30 \mathrm{ml}$ の結晶ざら数個に入れ,精ひ ょうした後, 室温で水蒸気を飽和させたデシケーター内
に放㯰して，金属表面を酸化させた１日，1 週間，2週 間後にそれぞれ试料を取り出し，デシケータ一内で 24 時間乾燥して, 試料の酸化による重量変化, $\Delta w$ を求 めた，又；本法によって酸化マグネシウムを定量した。

Fig. 4 は酸化過程に見ら机る重量变化の関数として, 試 料中の酸化マグネシウムを示した。酸化マグネシウムの 量と $\Delta w$ との間の良い直線関係は，金属マグネシウム 中の酸化マグネシウムを定量するのに，本法が十分に適 合していることを示すものである. 又，この酸化処理過 程では金属マグネシウムの表面に酸化マグネシウムだけ でなく，水酸化マグネシウム，炭酸マグネシウム，塩基 性炭酸マグネシウムなども形成されていると考毜られる ので，喔酸マグネシウムについて本法を適応した結果， Table 7 に示すように，その回収率は十分であった。ゆ えに本法では酸化マグネシウム以外の酸素化合物をもす ベて酸化マグネシウムとして定量しているとい方る。

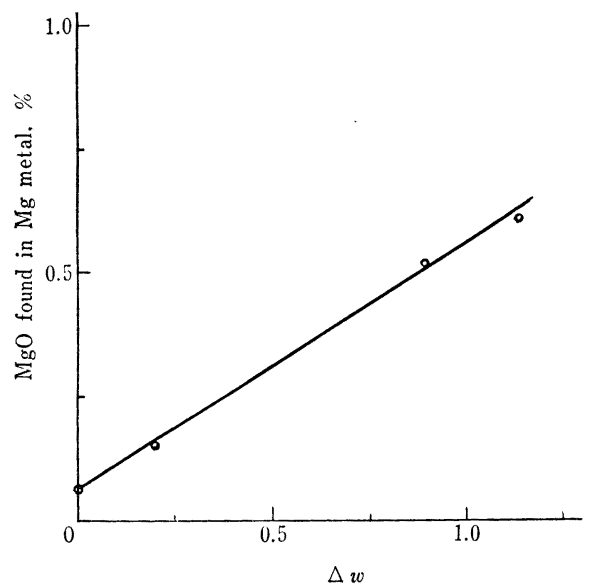

Fig. 4 The increase of the weight of magnesium metal during standing and the amounts of magnesium oxide determined by this method

Table 7 Recovery of $\mathrm{MgCO}_{3}$ after the reaction with phenol

\begin{tabular}{cccc}
\hline $\begin{array}{c}\mathrm{MgCO}_{3} \text { taken } \\
(\mathrm{mg})\end{array}$ & $\begin{array}{c}\text { (as } \mathrm{MgO} \text { taken) } \\
(\mathrm{mg})\end{array}$ & $\begin{array}{c}\mathrm{MgO} \text { found } \\
(\mathrm{mg})\end{array}$ & $(\%)$ \\
\hline 2.68 & $(1.28)$ & 1.17 & 91.4 \\
16.0 & $(7.65)$ & 7.63 & 99.7 \\
19.2 & $(9.19)$ & 9.14 & 99.5 \\
110 & $(52.5)$ & 54.1 & 103 \\
\hline
\end{tabular}

4 結言

本法によれば高純度の金属マグネシウム中に含まれる 
微量の酸化マグネシウムを，少量の試料を用いて，短時 間で再現性よく，高い精度で定量与ることができる。

$$
\text { ( } 1976 \text { 年 } 10 \text { 月，分析化学会 } 25 \text { 年会において一部発表) }
$$$$
\text { 交献 }
$$

1) H. J. Allsopp : Analyst, 81, 469 (1956).

2) F. Ferran, P. Belin : Compt. Rend., 259, 2645 (1964).

3) Kh. K. Ospanov, S. D. Alimpeva : Zavod. Lab., 37, 1045 (1971).

4) T. A. Hiller, V. A. Stenger : Anal. Chem., 46, 2019 (1974).

5) 木羽敏泰, 松本 健, 清水源治：本誌, 24, 116 (1975).

6) 小田仲涁, 沢辺重治：工化，59，1445（1956).

放

Determination of magnesium oxide in and on the high purity magnesium metal by the phenol dissolution method. Ken Matsumoto, Sadayuki Korzumi and Toshiyasu Kiba (Department of Chemistry, Faculty of Science, Kanazawa University, 1-1, Marunouchi, Kanazawa-shi, Ishikawa)

A $40 \mathrm{ml}$ of phenol was put in $100 \mathrm{ml}$ two neck round-bottom flask equipped with a conventional distillation device and a ground glass stopper, and heated to the boiling point of phenol, $180^{\circ} \mathrm{C}$. During this treatment, a slight amount of water contained in phenol was eliminated from phenol as the azeotropic vapor mixture of phenol and water at $99.5^{\circ} \mathrm{C}$, and phenol was thoroughly dehydrated. After the distillation device was replaced by a reflux condenser, a piece of magnesium metal sample was put quickly into the flask through the side neck. Then the content was heated under stirring at $180^{\circ} \mathrm{C}$, until magnesium metal diminished completely in phenol, forming magnesium phenoxide, while magnesium oxide remained as residue. The reaction mixture was cooled to (50 $60)^{\circ} \mathrm{C}$, and anhydrous methanol was added to keep phenol and magnesium phenoxide in dissolving form. The residual magnesium oxide was caught on a sintered glass filter (1G5) and dissolved in $50 \mathrm{ml}$ of $2 \mathrm{M}$ hydrochloric acid. The solution was diluted to a definite volume and magnesium in the solution was determined by the atomic absorption spectrometry. All the experiments were carried out in a glove box in dry nitrogen atmosphere to avoid the influence of oxygen and water from air. By the above procedure a minute amount of magnesium oxide could be determined precisely with high reproducibility. To clarify the behaviors of magnesium metal and magnesium oxide in this separation process additional experiments were also done.

(Received June 14, 1978)

\section{Keywords}

Atomic absorption

Magnesium metal

Magnesium oxide

Phenol dissolution 